\title{
PERFORMANCE OF METAKAOLIN AS PARTIAL REPLACEMENT OF CEMENT IN HOT MIX ASPHALT
}

\author{
A. A. Murana ${ }^{1}$, A. T. Olowosulu² and S. Ahiwa ${ }^{3}$ \\ 1,2 Dept of Civil EngineEring, Ahmadu Bello University, Zaria, Kaduna State. NIGERIA \\ 3 Works Department, AdamaWa State College of Education, Hong, P.M.B. 2237, Yola. NIGERIA \\ E-mail addresses: ${ }^{1}$ fatinoyi2007@yahoo.co.uk,2olowosulu_at@yahoo.com³ahiwasuleiman@yahoo.com
}

\begin{abstract}
Metakaolin is one mineral admixture that appears to have significant potential for the production of high strength and high performance concretes. This work investigates the performance of asphalt concrete containing Metakaolin partially replaced with cement. Oxide composition test on Metakaolin, tests on aggregates and cement, bitumen tests (consistency test) were carried out. Several mix containing different percentages of Metakaolin and ordinary Portland Cement was prepared to evaluate its strength using Marshall Stability Method of pavement design. It was found that at varying percentages of bitumen content, the stability, flow, voids in mixed aggregates and void in the mix meets the standard specified with an optimum bitumen content of $5.5 \%$.
\end{abstract}

Keywords: hot mix asphalt, marshall method, bitumen, metakaolin, cement

\section{INTRODUCTION}

The type of Hot Mix Asphalt (HMA) most frequently used in tropical countries are manufactured in an asphalt plant by hot-mixing of appropriate proportion of Coarse aggregate, fine aggregate, filler material and bitumen [1].

The filler material serves as void fillers which increase the densification of aggregates and also helps to determine the Optimum Bitumen Content (OBC) of the mixture. In selecting the filler, the quantity to be added depends on the amount of filler present in the aggregate, desired reduction in voids, the extent to which additional increment will decrease the OBC in the mix [2].

One of the major fillers used in HMA is cement. With the extensive use of cement in mortars/concrete, there have been some environmental concerns in terms of damage caused by the extraction of raw material and Carbon dioxide $\left(\mathrm{CO}_{2}\right)$ emission during cement manufacture. This has brought pressures to reduce the cement consumption in the industry [2].

Pozzalanas such as fly ash, limestone dust, blast furnace slag, rice husk ash, incinerator ash, billet scales, siliceous and ionic materials most of which are waste from farms and milling industries across the globe or those that require relatively less energy to manufacture are now used in construction because of their cementitious properties [3].

The utilization of calcined clay in the form of Metakaolin as a pozzolanic addition for mortar and concrete has considerable interest in recent years, much of this interest has focus on removal of calcium hydroxide, which is produced by the hydration of cement and provides enhanced strength [4].

Metakaolin (MK) which is produced by thermal treatment (calcinations of the high quality kaolin clay) at a temperature of about $650-800^{\circ} \mathrm{C}$ and a heating time of 90 minutes is found to have active pozzolana content which can be substituted or used as a filler material.

Murray [5] studied the pozzolanic behaviour of MK and its effect on cement and concrete properties. He revealed that calcined kaolin (MK) is a very effective pozzolana and results in enhanced strength in the concrete.

\section{MATERIALS}

Materials used include filler materials (Metakaolin and cement), aggregates (fine and coarse) and binder (bitumen). The fresh coarse and fine aggregate were obtained from Zaria in Kaduna State. The Ordinary Portland Cement was of Dangote brand and obtained from Samaru in Zaria, Kaduna State. The bitumen used

* Corresponding author, Tel: +234-803-637-6697 
was obtained from Nigeria National Petroleum Cooperation (NNPC) in Kaduna State.

\section{METHODS}

The methodology involves the experimental tests carried out to determine the physical properties of bitumen, coarse aggregate, fine aggregate, cement and the chemical properties of MK.

The tests carried out on the components of HMA are as follows:

1. Tests on bitumen (Penetration test (ASTM D5), Solubility test (ASTM D4), Viscosity test (ASTM D2170), Ductility test (ASTM D113), Flash and fire point test (ASTM D92) and Specific gravity test (ASTM D70))

2. Test on Metakaolin [6]

3. Experimental test on cement (Initial and Final setting time, Soundness test)

4. Test on aggregates (Aggregate impact value/hardness test (BS 812 PART 111), Aggregate crushing value (BS 812 PART 112), Aggregate specific gravity (ASTM C136), Size and gradation (BS 812-103.2), Specific gravity test (ASTM C136))

5. Marshall Test

\section{RESULTS AND DISCUSSION}

\subsection{Test on Bitumen}

The test results obtained are as shown in Table 1 . The results are within the limits of the code specifications, therefore the bitumen can be judge as good for usage.

\subsection{Test on Cement}

The results of the tests carried out on the physical properties of the cement for HMA and its comparison with standard is as presented in Table 2 .

\subsection{Test on Aggregate (Coarse, Fine and Filler)}

The results of the tests carried out on the aggregate materials and its comparison with standard are as presented in Table 3. It shows the strength properties which are measures of mechanical properties (crushing and impact tests) of the aggregate and specific gravity is a of measure aggregate density.

The values obtained from the tests on aggregates are substantially typical value for the aggregate favourable to the quoted code of specifications as such the aggregate is suitable for HMA design.

\subsection{Particle Size Distribution Curves for Aggregates}

The graphs of particle size distribution performed on the aggregates (Coarse and Fine) are as shown in Figures 1 and 2.

Table 1: Result of preliminary tests on bitumen

\begin{tabular}{|c|c|c|c|c|c|}
\hline \multirow[t]{2}{*}{ Test } & \multirow[t]{2}{*}{ Test Method. } & \multicolumn{3}{|c|}{ Specification by codes Penetration Grade } & \multirow[t]{2}{*}{ Value } \\
\hline & & $40 / 50$ & $60 / 70$ & $80 / 100$ & \\
\hline Penetration at $25^{\circ} \mathrm{C}$ & D5 & $40-50$ & $60-70$ & $80-100$ & 92 \\
\hline Viscosity & D4402 & $220-400$ & $120-250$ & $75-150$ & 192 \\
\hline Flash point \& Fire point $\left({ }^{\circ} \mathrm{C}\right)$ & D92 & 232 & 232 & 219 & 243 \\
\hline Solubility in trichloroethylene (\%) & D2042 & 99 & 99 & 99 & 99 \\
\hline Ductility $25^{\circ} \mathrm{C}$ min. & D113 & - & 50 & 75 & 75 \\
\hline Specific Gravity at $25^{\circ} \mathrm{C}$ & D70 & $0.97-1.02$ & $0.97-1.02$ & $0.97-1.02$ & 1.00 \\
\hline
\end{tabular}

Table 2: Comparison of Test Result on Cement with Standard

\begin{tabular}{llll}
\hline Test & Value & Code Used & Code Specification \\
\hline Initial Setting Time (min) & 68 & BS EN 196 PART 3 (1995) & $>45 \mathrm{~min}$ \\
Final Setting Time (min) & 255 & BS EN 196 PART 3 (1995) & $<10 \mathrm{hrs}$ \\
Soundness (mm) & 3.1 & BS EN 196 PART 3 (1995) & $<10 \mathrm{~mm}$ \\
Specific Gravity & 3.1 & ASTM C188 & 3.15 \\
\hline
\end{tabular}

Table 3: Comparison of Test Result on Aggregate with Standard

\begin{tabular}{llll}
\hline Test & Value & Code Used & Code Specification \\
\hline Aggregate Crushing Value (\%) & 22.12 & BS 882 PART 112 & $<30$ \\
Aggregate Impact Value (\%) & 21.31 & BS 882 PART 112 & $<30$ \\
Specific Gravity (Coarse) & 2.5 & ASTM C136 & $2.6-2.9$ \\
Specific Gravity (Fine) & 2.62 & ASTM C136 & $2.6-2.9$ \\
\hline
\end{tabular}


The Figure 2 shows the graphical representation of the particle size distribution curve for the fine aggregate. From the graph, it shows that the fine aggregates falls within range as specified by BS 882 . The normal minimum size is generally less than $4.76 \mathrm{~mm}$.

\subsection{Test on Metakaolin}

The collected sample of MK was taken for elemental analysis using energy dispersive microprocessor controlled analytical instrument designed for detection and measurement of elements in a sample. The analysis was carried out according to [6] to determine the oxide composition of MK. The result is as shown in Table 4.

The test result obtained was compared with those specified by [6] for use as admixture in concrete as shown in Table 5 below.

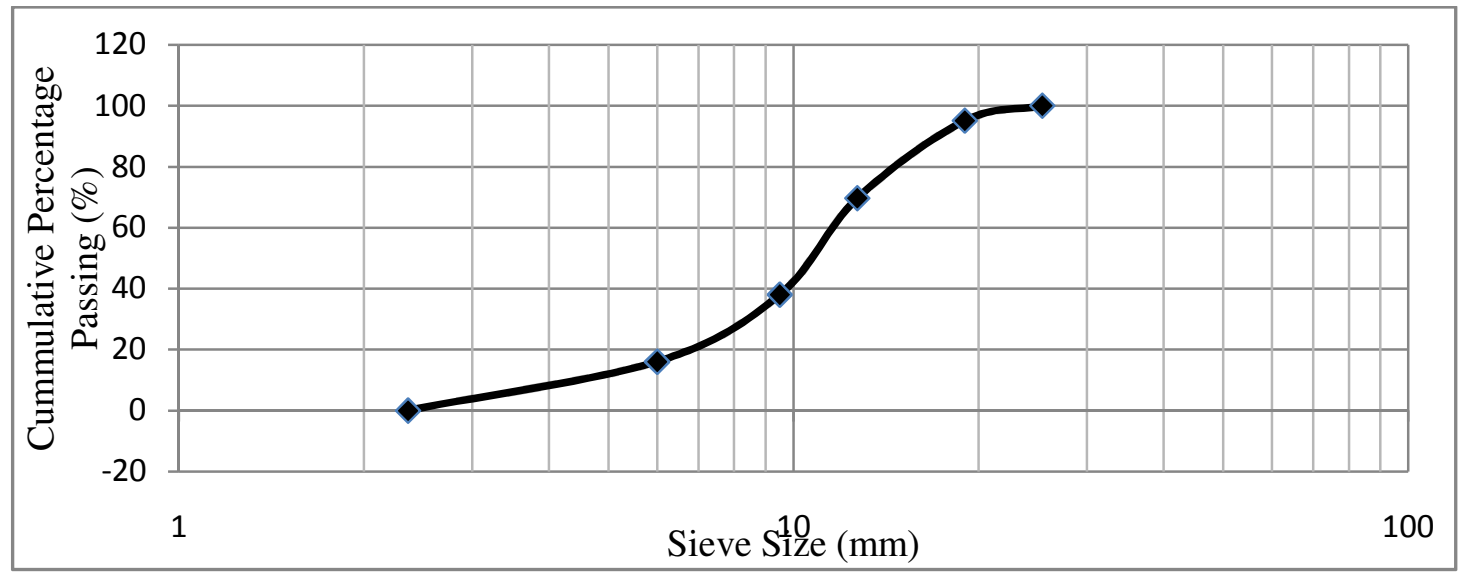

Figure 1: Particle Size Distribution Curve for Coarse Aggregate

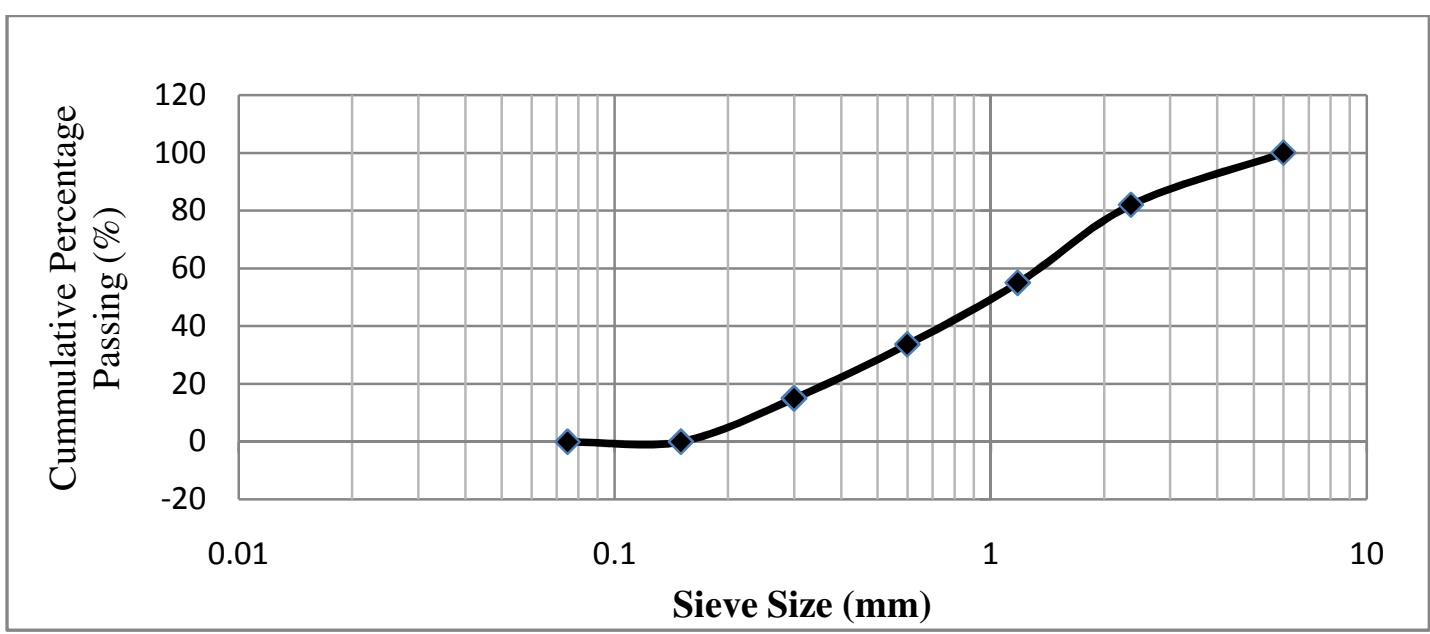

Figure 2: Particle Size Distribution Curve for Fine Aggregate

Table 4: Oxide Composition of Metakaolin

\begin{tabular}{cccccc}
\hline Compound & \% present & Compound & \% present & Compound & \% present \\
\hline $\mathrm{Al}_{2} \mathrm{O}_{3}$ & 30.7 & $\mathrm{SiO}_{2}$ & 54.4 & $\mathrm{Fe}_{2} \mathrm{O}_{3}$ & 5.46 \\
$\mathrm{P}_{2} 0_{5}$ & 0.6 & $\mathrm{~K}_{2} \mathrm{O}$ & 2.03 & $\mathrm{SO}_{3}$ & 0.91 \\
$\mathrm{Re}_{2} \mathrm{O}_{7}$ & 0.2 & $\mathrm{TiO}_{2}$ & 0.27 & $\mathrm{CaO}$ & 1.45 \\
$\mathrm{~V}_{2} \mathrm{O}_{5}$ & 0.073 & $\mathrm{Cr}_{2} \mathrm{O}_{3}$ & 0.084 & $\mathrm{MnO}$ & 0.18 \\
$\mathrm{NaO}$ & 1.36 & $\mathrm{CuO}$ & 0.089 & $\mathrm{ZnO}$ & 0.02 \\
$\mathrm{BaO}$ & 0.29 & $\mathrm{Ga}_{2} \mathrm{O}_{3}$ & 0.009 & $\mathrm{Rh}_{2} \mathrm{O}_{3}$ & 1.6 \\
\hline
\end{tabular}


Table 5: Comparison of test result on Metakaolin with ASTM Standard

\begin{tabular}{lllll}
\hline Mineral Admixture Class & & & & Test Result \\
& $\mathrm{N}$ & $\mathrm{F}$ & $\mathrm{C}$ & \\
\hline $\mathrm{SiO}_{2}+\mathrm{Al}_{2} \mathrm{O}_{3}+\mathrm{Fe}_{2} \mathrm{O}_{3} \min , \%$ & 70 & 70 & 50 & 90.5 \\
$\mathrm{SO}_{3} \max , \%$ & 4 & 5 & 5 & 0.91 \\
\hline
\end{tabular}

From Table 5, it is observed that MK used for this research is of class $\mathrm{N}$ and can be said to be pozzolanic which can be used as a partial replacement of cement in HMA design.

\subsection{Marshall Test}

Marshall Test plans include an effective proportioning of a trial mix. Three (3) specimens each were made for each of the bitumen content making a total of twelve (12) specimens. The test was in accordance to Marshall Test [7]. The Combined graph showing the relationship of Marshall Properties with bitumen content for mixes containing varying proportion of fillers are shown in figure 3 to 8 from which the Marshall Test results are discussed.

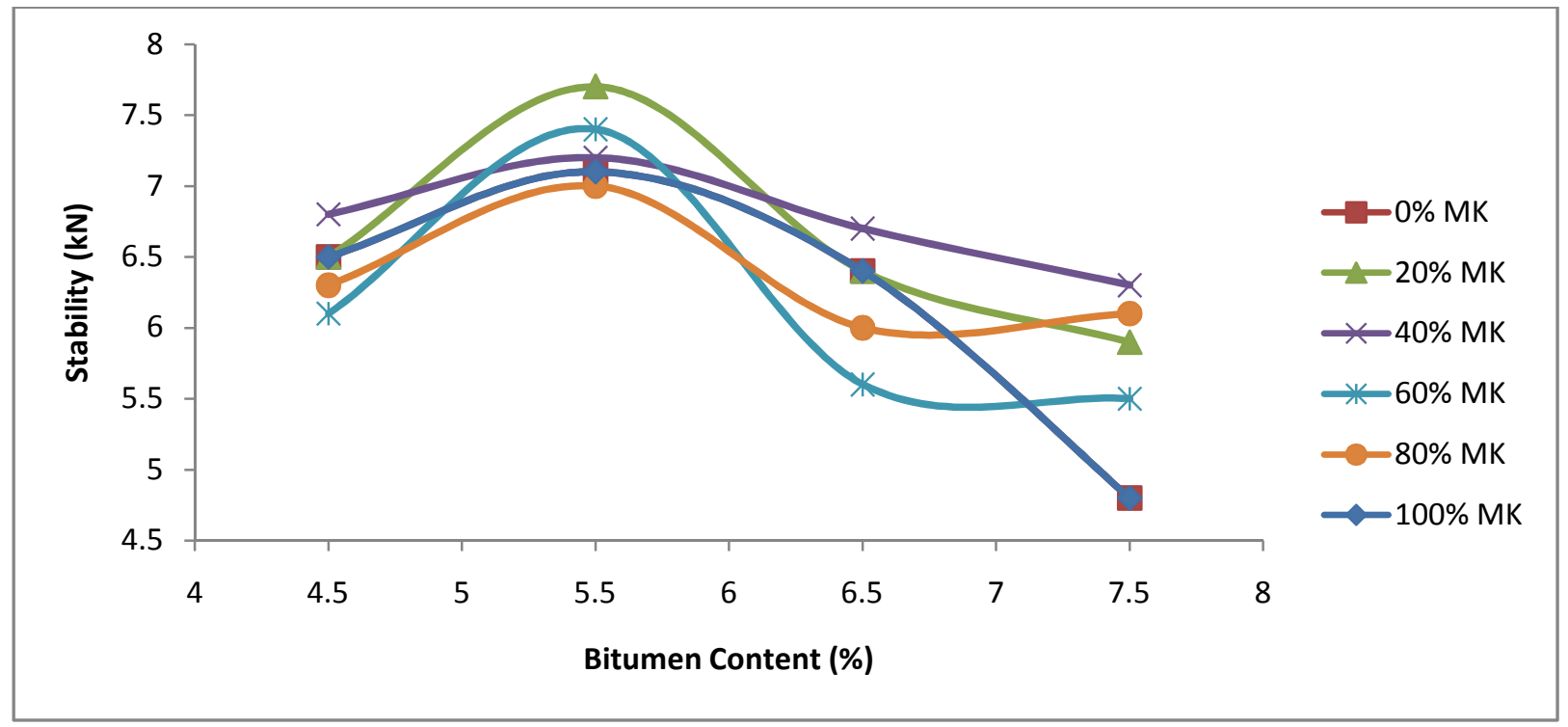

Figure 3: Combined Graph of Stability Vs Binder content

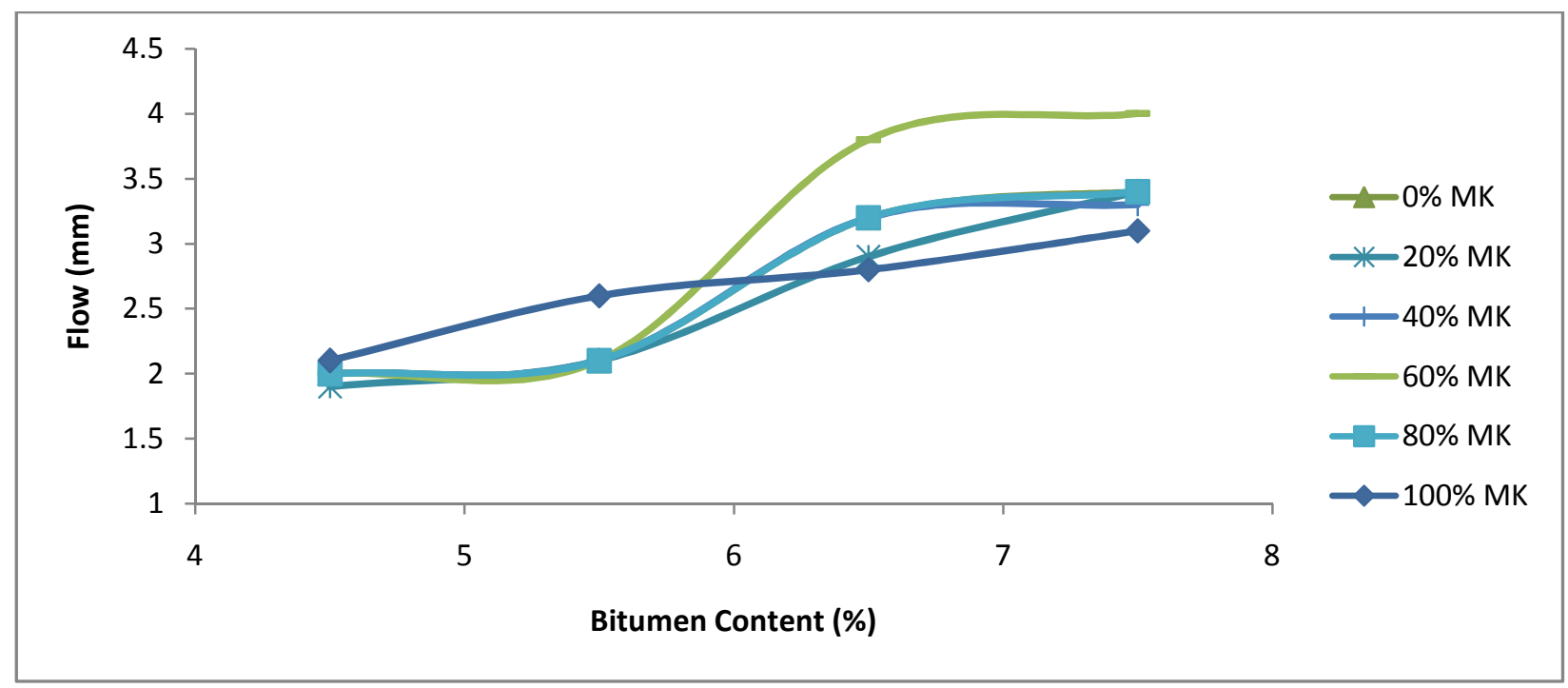

Figure 4: Combined Graph of Flow Vs Binder content 


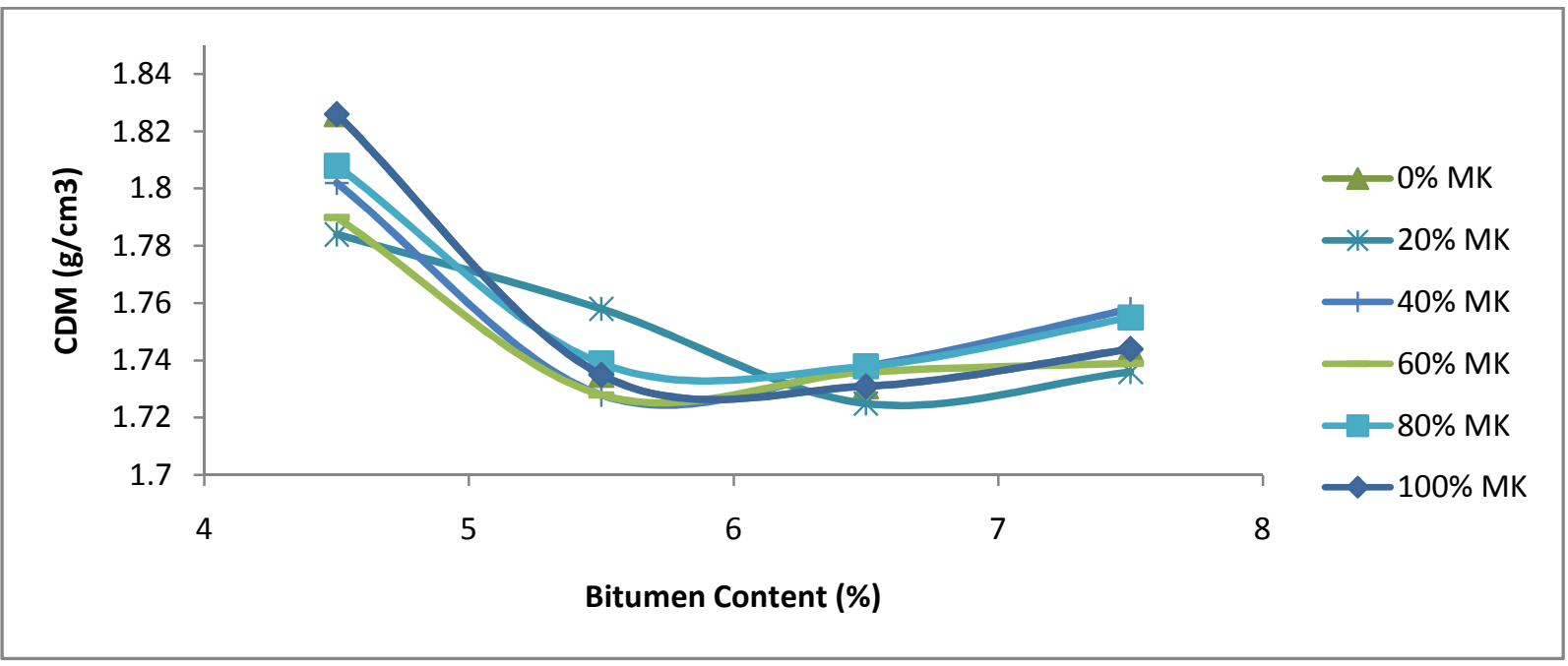

Figure 5: Combined Graph of CDM Vs Binder content.

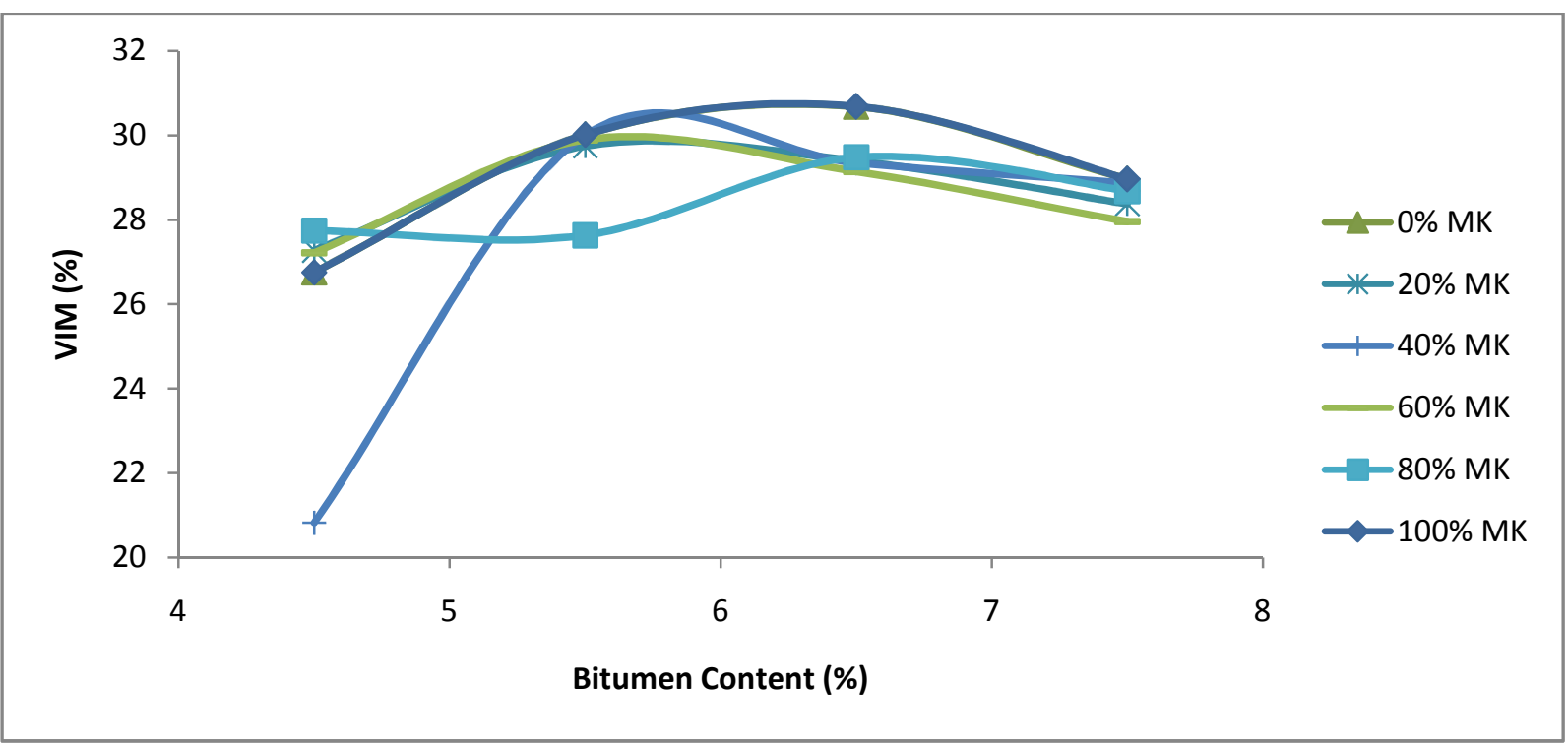

Figure 6: Combined Graph of VIM Vs Binder content

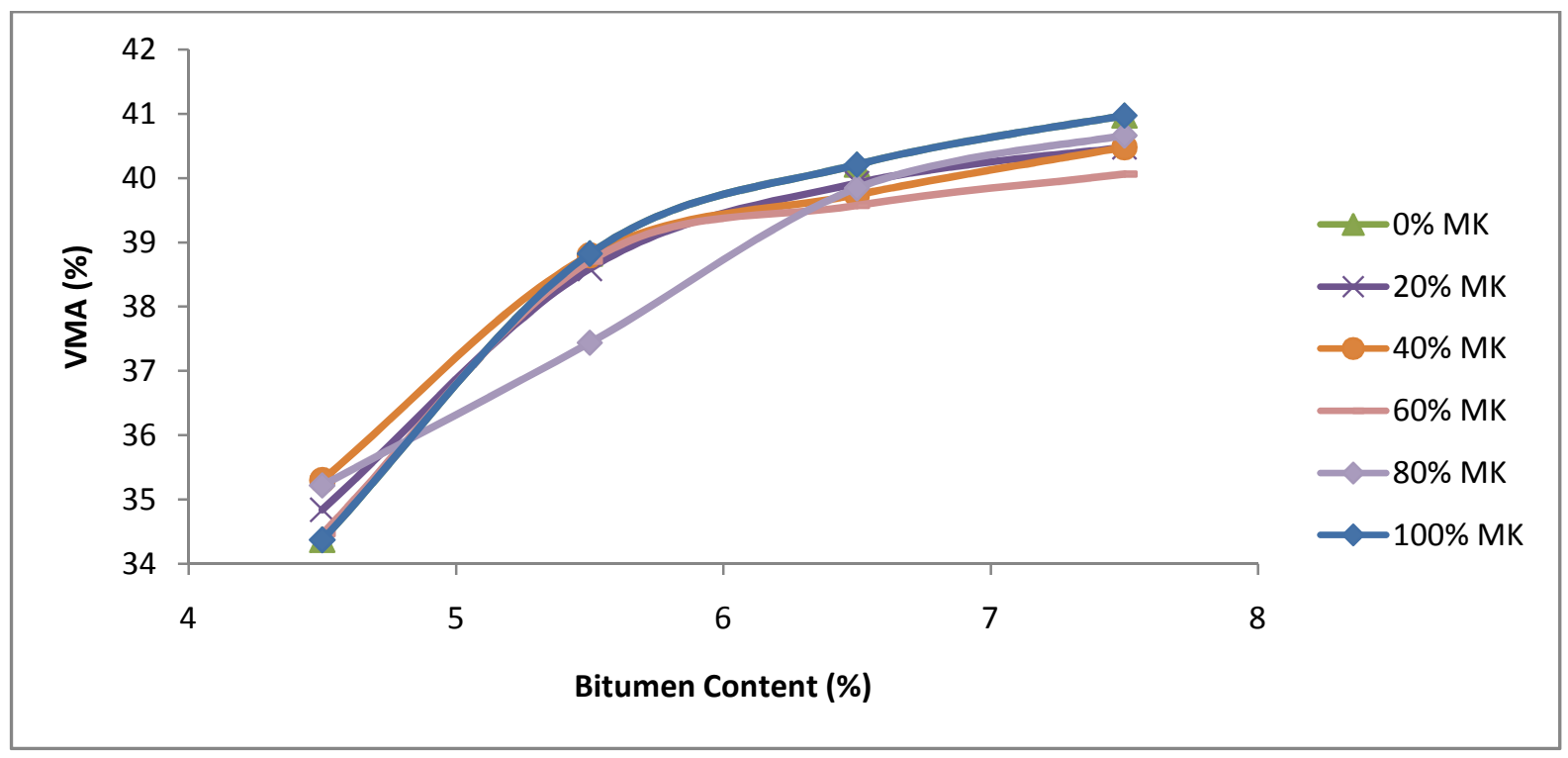

Figure 7: Combined Graph of VMA Vs Binder content. 


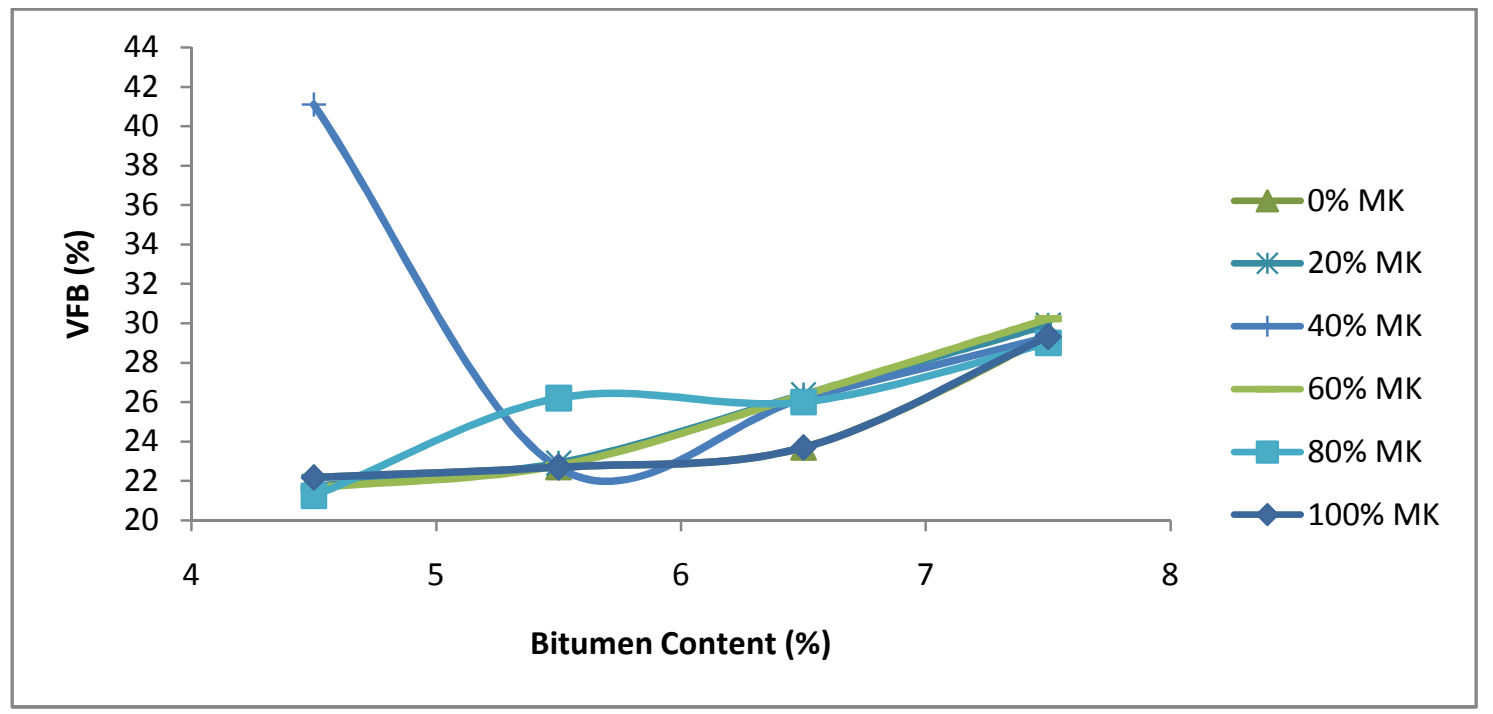

Figure 8: Combined Graph of VFB Vs Binder content

\section{DISCUSSION OF RESULTS}

The bitumen test results are within code specifications and can be used for bituminous mix design and it is $80 / 100$ grade. The aggregate is of well graded materials and fully satisfies the specifications of codes used in terms of strength and specific gravity. The cement satisfies the codes used for setting times and specific gravity. The MK used is a good pozzolana material with $90.56 \%$ pozzolanic content which meets [6] recommendation. From Figure 3, it was noticed that the stability increase with increase MK content to a maximum value then drops as the MK content increases, but the drop can be said to be negligible with the optimum bitumen content for the stability of mix design as being 5.5 percent. It was noticed in figure 4 that the higher the bitumen content, the higher the flow. However, the flow of $2-2.1 \mathrm{~mm}$ is fairly constant between 4.5 - 5.5 percent bitumen content. In figure 5, the VFB increases with increase in bitumen content. At optimum bitumen content of 5.5 percent, the value of VFB is fairly constant and has a value of 22.6 percent. The VIM value of zero percent MK in figure 6 is lowest while that of 100 percent is highest. For the relevant parameters to estimate optimum bitumen content i.e. stability, CDM and VIM, values of bitumen content is fairly constant at 5.5 percent. Figure 7 shows the relationships between VMA and bitumen content. It showed fairly positive slope which means that the VMA increases with bitumen content, 5.5 percent bitumen content gave rise to a constant VMA value of 19 percent for all values of MK. In figure 8, the graphs are fairly positive curves whose values of VFB increase with increasing bitumen content. At 5.5 percent bitumen content, the value of VFB for all values of MK is fairly constant at 22.7 percent.

\section{CONCLUSION}

The following conclusions were drawn from the study:

1. The Metakaolin used is a pozzolana and conforms to [6] requirement which has great potential for use in concrete.

2. The value for the required properties of bitumen as a binder as regards its penetration, viscosity, flash and fire point, ductility and solubility all conforms to those of the ASTM standard specification for the design of asphalt concrete.

3. The aggregate Crushing Value, aggregate Impact Value, Specific Gravity of coarse aggregate, Specific Gravity of fine aggregate was within specification.

4. The mix at varying percentages of bitumen content meets the standard specified in terms of stability, flow and VMA and VIM and at an optimum bitumen content of 5.5\%.

\section{RECOMMENDATIONS}

1. Mechanical properties such as tensile strength, flexural strength, and elastic modulus should be investigated in future research as this will widen the application of Metakaolin in asphalt concrete because Axle weight has an overwhelming effect on asphalt concrete [8] and Ani and Isimijola [9] conclude that at low traffic intensities the behaviour of the distribution varies while at high traffic intensities they behave alike.

2. Natural clays from various parts of the country should be further investigated to ascertain the 


\section{Performance Of Metakaolin As Partial Replacement Of Cement In Hot Mix Asphalt $\quad$ A. A. Murana, et al}

pozzolanic properties of the various clay deposits in Nigeria.

\section{REFERENCES}

[1] Jackson G.P and Brien D. "Asphaltic Concrete" London: Shell International Petroleum Company, Limited. 1962, pp. 5-9

[2] Malhotra, V. M. Fly ash, Silica Fumes, Slags and Natural Pozzolans Concrete, Proceedings Second International Conference, Madrid, and Spain, 1986.

[3] Abarshi, M.D. Use of Billet Scales as Filler in Asphaltic Concrete. Unpublished Postgraduate Thesis, Civil Engineering Department, Ahmadu Bello University, Zaria Nigeria, 1988.

[4] Wilt S., Khatib J. M, Jones A. "Relative Strength, Pozzolanic Activity and Cement Hydration in Super Plasticized Metakaolin Concrete" Cement Concrete Res. 26(10), 1996, pg1537-44.
[5] Murray, H.H. Traditional and New Application for, Smectic and Palygorskite: A General Overview, Applied Clay Science Volume 17, Issue 5, 2000, pp.207-221

[6] American Society for Testing and Materials C618, Standard Specification for Coal Fly Ash and Raw or Calcined Natural Pozzolana for Use as a Mineral Admixture, ASTM International, 2001

[7] Asphalt Institute. Principles of Construction of HotMix Asphalt Pavements: Manual Series, No. 22 (MS22), Maryland, 20740,USA, 1983.

[8] Murana, A. A., Olowosulu, A. T. and Otuoze, H. S. "Minimum Thresholds of Monte Carlo Cycles for Nigerian Empirical-Mechanistic Pavement Analysis and Design System". Nigerian Journal of Technology, Vol. 31, No. 3, pp. 321 - 328, 2012.

[9] Ani, C. I. and Isimijola, S. O. Effect of Data Traffic Patterns on QoS Parameters. Nigerian Journal of Technology, Vol. 28 No.2, 2009, pp 23 - 28. 